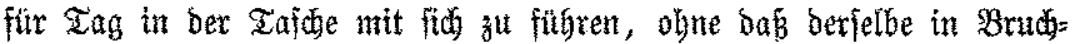

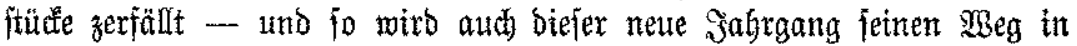
zablreide Forattäuljer finben.

\title{
IV. Allatizen.
}

\section{Jubiläumsfeier.}

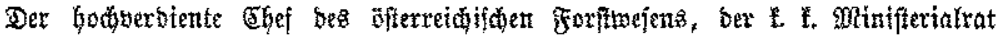

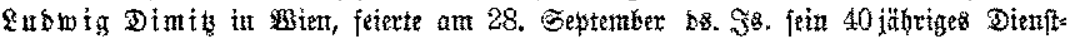

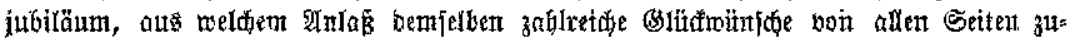

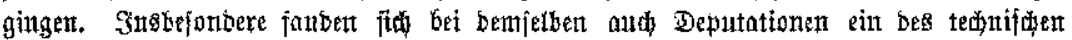

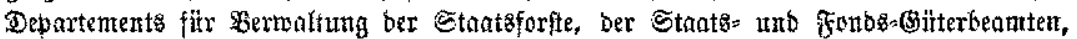

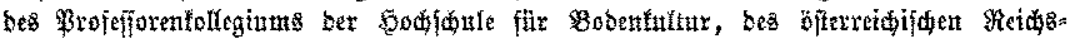

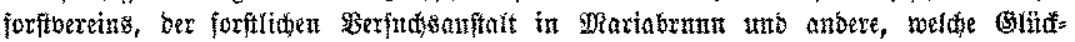

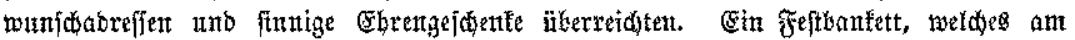

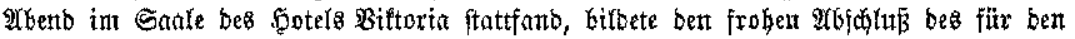
(Sefeierten fo ehrenbolfen Iagez - möge es bemfelben vergännt fein, aut nod bie

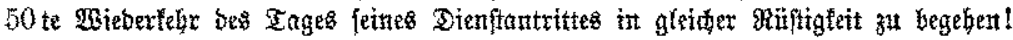

\section{Die Zufforftung von D̈sländereien in preuzen.}

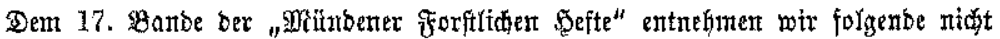

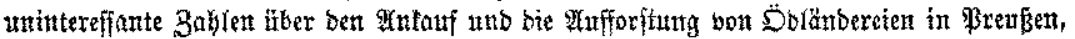

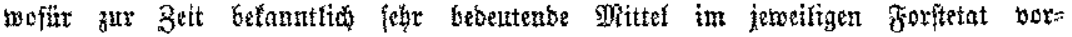
gếęen weroen.

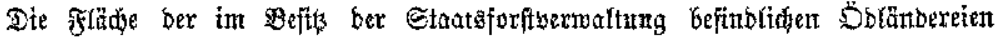

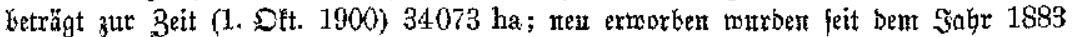

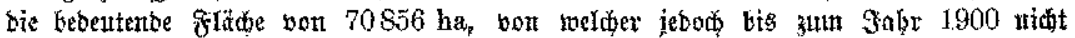
meniger ats 61620 ha - jutah pro $3 a$ a 3625 ha - entgeforfet worben firt.

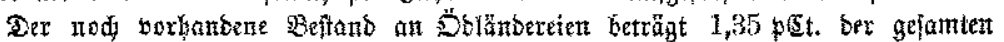

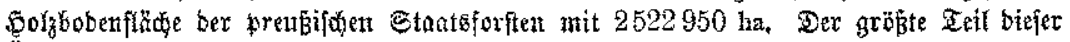

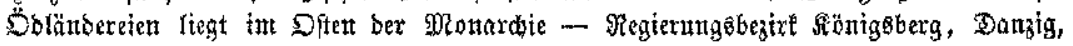

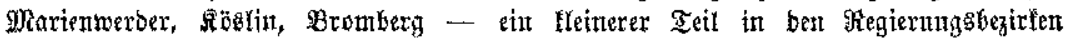

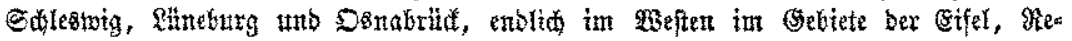

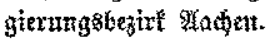

\section{Samenerntes Bertįt dev firma Gütav Shott in 2lihaffenburg.}

Die (sidelernte liefert heuter forobl bei ber Stisleide (Quercus pedunculata)

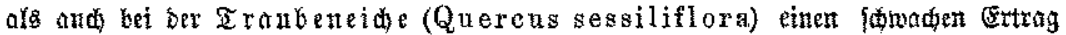

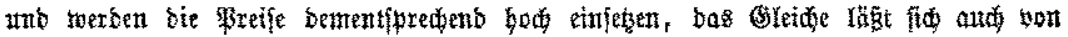

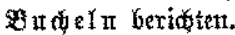

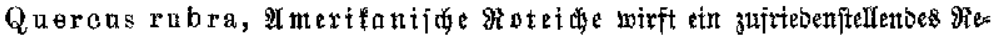
fultat ab unto fectent bie seeife billig ein. 